\title{
USE OF INTERACTIVE TEACHING METHODS IN THE TEACHING OF NATURAL SCIENCE COURSES TO STUDENTS TRAINING ON TECHNOLOGICAL PROGRAMS
}

\author{
Natalia Vasilievich ${ }^{1^{*}}$, Tamara Sharova $^{2}$, Marina Artamonova ${ }^{3}$, and Julia Bukhteeva ${ }^{4}$ \\ ${ }^{1}$ Prof, Dr, K.G. Razumovsky Moscow State University of Technologies and Management, \\ RUSSIA, n.vasilievich@mgutm.ru \\ ${ }^{2}$ Prof, Dr., K.G. Razumovsky Moscow State University of Technologies and Management, \\ RUSSIA, t.sharova@mgutm.ru \\ ${ }^{3}$ Prof, Dr, Moscow State University of Food Production, RUSSIA, artamonovaMP@mgupp.ru \\ ${ }^{4}$ Prof, Dr, Moscow State University of Food Production, RUSSIA, bukhteeva.julia@yandex.ru \\ ${ }^{*}$ Corresponding Author
}

\begin{abstract}
The paper provides information on the results of the use of interactive teaching methods in the teaching of chemical courses to students of the training bachelor programs of the enlarged group 190000 "Industrial ecology and biotechnology». Particular attention is paid to such methods as the case-study, the activation of creative activity, lecture-visualization, web-quest. The positive influence of the use of these methods on the results of students mastering the main educational program has been established.
\end{abstract}

Keywords: interactive methods, lecture-visualization, case-study, situational tasks, web-quest, cinquain.

\section{INTRODUCTION}

Currently, there is a change in the priorities of the education paradigm. The formation of the competencies of a bachelor should be closely related to the development of his ability to solve problems and tasks of different complexity levels that arise in real situations of professional activity. Moreover, the student must be able to prove their professional effectiveness with real achievements and results. The student is a subject in learning, he participates in the cognitive process, actively performing various types of tasks: creative, research, problematic. The necessary conditions for the formation of general cultural and professional competencies of students are as follows: the creation of professionally developing situations, the cooperation of teachers and students, professional positioning. It should also be noted the required use of business games, methods for analyzing specific situations; formation of a system of cognitive and professional motives [Цыбулько, 2016, р.863]. The modernization of the educational process involves improving the quality of teaching by introducing innovative learning technologies, methods, forms and training in accordance with modern technical and social achievements. In this regard, the creative work of the university teacher should be aimed at finding completely new teaching methods and techniques. As the organizer and leader of the student's educational activities, the teacher must provide the educational process in the taught discipline with methodological support based on innovative teaching technologies. The implementation of the competency-based approach involves carrying out training sessions using active and, 
above all, interactive teaching methods. In the requirements of the federal state educational standard of higher education, the share of classes conducted in interactive forms is the main goal of the main educational program. The total hours of these classes is determined by the contingent of students and the content of specific courses. In areas of bachelor training for food processing enterprises and the agroindustrial sector, special attention is paid to the wide use in the educational process of interactive forms of conducting classes in combination with extracurricular activities. In the bachelor's training program, such classes should be at least $20 \%$. The fulfilment of this requirement supposes, first of all, the transformation of the information-controlling function of a teacher into a consultative-coordinating function. Based on the foregoing, it can be argued that interactive methods are a trend in modern higher education.

\section{RESULTS AND DICUSSION}

Interactive methods are commonly understood as teaching methods based on the interaction of students with each other. Interactive learning technologies are a way to implement the content of training provided for by curricula, representing a system of forms, methods and teaching aids providing the most effective achievement of goals [Кустарева, 2018]. This scientific and methodological work is aimed at moving to slightly different forms, while the learning vector shifts from knowledge to skills. A technology is applied that takes into account the individual characteristics of students, and individualization of training is carried out by the number of hours and time. This allows capable students to more deeply master educational material of increased complexity, while less able ones study the required material. To achieve the goal of increasing the scientific and cognitive activity of students, the task was set to rationally organize the educational activities of students, purposefully managing it. Modern pedagogical science has an extensive arsenal of interactive methods. Using them, the teacher can involve the entire contingent of students who are actively involved in the cognitive process, perform creative, research, problem tasks in the educational process. Interactive teaching methods include creative tasks, work in small groups, educational, business and role-playing games, trainings, case technology methods, etc. Lectures as well as laboratory and practical classes can be conducted in an interactive form. A lecture with pre-planned mistakes, a lecture-visualization, a lecture together, a lecture-press conference, a lecture-dialogue, a lecture with elements of a business game are the most interesting for students. Of all these types of interactive lectures, lectures-visualizations with elements of lecture-conversation and lecture-dialogue are most used. [Гоева, 2016, р.11]. During the lecturevisualization, the transfer of information by the teacher is accompanied by a demonstration of the presentation, drawings, photographs, diagrams, plans, structural-logical and reference schemes. In the preliminary preparation of visual materials for the lecture - visualization, the teacher structures, systematizes and identifies the most significant and significant blocks of the content of the topic. Visual material is selected taking into account the specifics of the taught discipline, so as to achieve a concentration of students on the most significant aspects of each topic, help to better understand and learn the educational material. The proportion of text blocks in the lecture-visualization does not exceed $25-30 \%$. It consists mainly of the problems considered at the lecture, a list of questions for independent study, wording of laws, a glossary, a list of literature and other sources on the subject of discipline. The educational material presented in this form encourages the student to highlight the main thing, and serves as a support for mental and practical actions. He also forms the skills of confident work with diagrams, tables, and other forms of visualization, which creates the prerequisites for the development of professionally significant competencies. The use of multimedia when giving lectures increases the degree of interaction of the teacher-lecturer with students, provides an additional opportunity to ask them questions, monitor emotional feedback. Practiceoriented and personality-oriented approaches in the educational process are implemented through such an interactive learning method as the case study method. Case technology is a modern educational technology based on the analysis of some problem situation. It combines role-playing games, the project method, and situational analysis. Case study is the study of a subject by considering a large number of situations and tasks in a certain combination. The task of the case method is to maximize the involvement of each student in active independent work to solve a particular educational problem. The case method is a method of active learning based on real situations, and in Russia it is called the method of situational analysis. The essence of the case-study method is to use specific learning situations that guide students to formulate the problem and search for solutions to it, followed by discussion in the classroom. [Царапкина, 2015, p.120] The goal of the case study is to help each student determine their own path to mastering the knowledge that he most needs. Thus, a student enters into self-education, which corresponds to modern requirements for education. It should be noted that the case study is not a repetition of a teacher, not retelling, not an answer to a teacher's question, it is an analysis of a specific situation that forces one to raise the layer of knowledge gained and apply it in practice. This method contributes to the development of skills: analysis of the situation; choosing the optimal solution; evaluation of alternative tasks, interpersonal communication. We have introduced situational tasks and exercises and the method of analysis of specific situations (case) into the practice of 
teaching, as the most relevant to the content and specificity of the taught courses. In the natural sciences, cases were developed for each module. These are, as a rule, tasks and tasks of a practical, training and educational research nature. Cases are performed by students in a small group. Depending on the volume and content of the training module, the number of people in a group can be two, three or four. The best option is a group of three people. Objects and sources of situational tasks are food raw materials and products of plant and animal origin. During the performance of these tasks, students develop skills in setting goals and objectives, skills in working with devices, equipment, and interpreting the results of scientific research. During the consideration of the options that have arisen, the argumentation of the position of each student in a small group is discussed by all students of the study group, and the teacher only sums up the discussion. The method of specific situations (case-study) is a method of active problem-situational analysis based on training by solving specific tasks-situations. This method of interactive learning relates to nongame simulation methods, which allows you to apply theoretical knowledge to solve practical problems. A specific situation is an event that includes a contradiction or appears in conflict with the environment. Students are offered illustrative and educational situations whose tasks are to teach students both individually and as part of a group to analyse information; sort information to solve the selected problem; identify key problems of the proposed situation; generate alternative solutions and evaluate them; choose the best solution and formulate action programs. We have developed case studies for the Vitamins, Hormones, Lipids, and Physiology of Microorganisms sections. Methodological materials include case study, student instruction, information material and literature sources, and the Internet, and the university's local area networks. The analytical activity of students consists in applying theoretical knowledge about the structure, properties, and mutual transformations of bioorganic substances. Student work on the proposed situations includes stages that require both reproductive knowledge of the actual material and a creative approach using non-standard solutions. As the content of cases, in addition to texts of scientific, popular science literature, scientific publications and monographs of teachers of the department are widely used. A feature of these sources is the relevance, novelty of the material, as well as a pronounced professional and regional focus. The use of this technology in the educational process can significantly increase students' interest in the studied discipline and their educational motivation. Performing case studies by students encourages creative debate, stimulates them significantly and gives them a sense of satisfaction from their work. The active perception of educational information requires, in addition to a special organization, wellthought-out ways of presenting acquired knowledge. One of these methods is the visualization of educational material. To visualize the content of educational material in pedagogical practice, such forms as graphs, metaplan, memory card, semantic chain, matrices, synoptic diagrams, supporting synopsis, etc. are used as well as their combinations. Together with the case study package, students receive guidelines on material visualization technology. Another interactive method that we have successfully used is the WebQuest method. Currently, most often in higher education, this method is used to organize the independent work of students studying in the areas of the humanities and economics. However, in the literature there is practically no information on the use of this technology in the natural sciences. In general, the WebQuest is an educational site dedicated to students' research work on a specific topic with hyperlinks to various web pages. Having studied the structure of the "classic" WebQuest and the templates for its creation, we have prepared methodological support for extracurricular work of students in the taught disciplines. Since most of the number of hours of independent work on the course "Biochemistry" are in the section "Biochemistry of organs and tissues", the themes of this section "Bone tissue chemistry", "Blood biochemistry" were selected for the development of WebQuest. The task for students on the topic involves the search and systematization of information, the presentation of materials from various sources in the form of a presentation, as well as the justification of their own point of view on the studied problem and conclusions. The WebQuest task is issued for a group of students (2-3 people), in which they themselves distribute the roles. Web-quest allows you to organize an independent work in which students look for information on a specific topic of the course on the Internet. The teacher develops the WebQuest task, including a description of the initial situation, a goal, a list of questions, a list of links to information network resources, explanations on the processing of the information received. The instruction includes deadlines, a report form for the work, and evaluation criteria. The student's task is to process, structure and form information in a special way. The teacher must carefully work out the evaluation criteria, which must correspond to the result, be measurable, establish the level and quality of performance, relate to the process, product or knowledge. In addition, the teacher should also prepare links to adequate network resources. A WebQuest task is issued as a separate file. Performing a web quest, students gain skills in analyzing, synthesizing and evaluating information, expand and refine the basic concepts of the discipline, learn to disclose causal relationships, highlight the main idea and minor information. Cinquain is a methodological device of a personality-oriented approach to learning, which allows you to activate the cognitive activity of students. Cinquain is a five-line poetic form, written in accordance with certain rules and has a pronounced emotional coloring. Each line contains a set of 
words that must be reflected in the poem. Working on the creation of cinquain, the student realizes and develops his intellectual, creative abilities. Development of cinquain requires the student to carefully study the material on this topic, the ability to find the most essential educational elements in the educational material to draw a conclusion and express it briefly. An indicator of the correct cinquain is the recognition of its topic without reading the first line, only when meeting 2-5 lines. This method of activating the student's creative activity is also mainly used in the teaching of the humanities. However, we have successfully proposed a cinquain methodology for using in the study of chemical courses. According to the course "Chemistry" it is proposed to compose a cinquain for one of the concepts: atom, electron, molecule, nucleons, oxidation state, element, ion, corrosion, valency. In the discipline "Biological chemistry": vitamin, hormone, lipids, DNA, enzyme, inhibitor, activator, coenzyme. A student presents a cinquain compiled by him in a colourfully designed drawing, collage, etc. For example, cinquain about inhibitor and enzyme:

\begin{tabular}{|c|c|}
\hline $\begin{array}{c}\text { Inhibitor } \\
\text { Competitive, non-competitive, } \\
\text { Pause, slow down, } \\
\text { Helping, bring down } \\
\text { Savior. }\end{array}$ & $\begin{array}{c}\text { Enzyme } \\
\text { Live, Protein, } \\
\text { Acts, accelerates, does not change, } \\
\text { How metabolism can be without it! } \\
\text { Catalyst. }\end{array}$ \\
\hline
\end{tabular}

The current and intermediate control in the disciplines revealed that the interactive methods that we are introducing allow us to optimize the educational process, increase the educational motivation, strengthen the performing, creative activity and independence of students, as well as ensure high-quality assimilation of students in the academic courses.

\section{REFERENCE LIST}

1. Цыбулько Г.Я., Пшеничный М.В. (2016). Смена образовательной парадигмы как ведущая тенденция инновационных изменений в системе современного образования. Молодой ученый, №2 (106). [Tsibulko Gyu, Pshenichnyi MV. (2016). Changing the educational paradigm as a leading trend in innovative changes in the system of modern education. Molodoyi ucenyi. №2 (106). (In Russ)] https://moluch.ru/archive/106/24958

2. Кустарева Ж.В. (2018). Формирование общекультурных и профессиональных компетенций студентов высших образовательных учреждений в процессе применения педагогических технологий. Международный студенческий научный вестник, № 6. [Kustareva ZV (2018). Formation of general cultural and professional competencies of students of higher educational institutions in the process of applying pedagogical technologies. International Student Scientific Herald. № 6. (In Russ)] http://www.eduherald.ru/ru/article/view?id=19436

3. Гоева В.В., Миронов К.Е. (2016). Использование активных и интерактивных методов обучения при изучении технических дисциплин в вузах. Карельский научный журнал, T. 5, №2. [ Goyeva V.V., Mironov K.E. (2016) The use of active and interactive teaching methods in the study of technical disciplines in universities. Karelian scientific journal, Vol. 5, №2 (In Russ)]

4. Царапкина Ю.М. (2015) Использование кейс-технологий при обучении студентов. Образование $и$ наука, №3 (122). [Tsarapkina Yu.M. The use of case technology in teaching students. Education and science, №3 (122). (In Russ)] 